\title{
Bovine-Specific Nucleotide Polymorphisms and mRNA Expression of the Growth Hormone Secretagogue Receptor 1a (GHSR 1a) Gene and its Genetic Association with Growth and Carcass Traits
} Masanori Komatsu ${ }^{1 *}$, Yoichi Sato ${ }^{2}$, Yuki Fujimori ${ }^{3}$, Tomohito Itoh ${ }^{4}$, Masahiro Satoh ${ }^{1}$, Motohide Nishio ${ }^{1}$, Osamu Sasaki ${ }^{1}$, Hideaki Takahashi ${ }^{1}$ and Aduli EO $^{\text {Malau-Aduli }}{ }^{5}$

${ }^{1}$ NARO Institute of Livestock and Grassland Science, National Agriculture and Food Research Organization (NARO), Tsukuba, Ibaraki, Japan

${ }^{2}$ Animal Industry Research Institute, Iwate Prefecture Livestock Research Centre, Takizawa, Japan

${ }^{3}$ Nagano Prefecture Livestock Research Centre, Shiojiri, Japan

${ }^{4}$ Maebashi Institute of Animal Science, Livestock Improvement Association of Japan, Inc. (LIAJ), Maebashi, Japan

${ }^{5}$ Animal Science \& Genetics, Tasmanian Institute of Agriculture, School of Land and Food, University of Tasmania, Hobart, Tasmania, and School of Veterinary \& Biomedical Sciences, Faculty of Medicine, Health \& Molecular Sciences, James Cook University, Townsville, Queensland, Australia

${ }^{*}$ Corresponding author: Masanori Komatsu, Animal Breeding and Genetics Research Group, NARO Institute of Livestock and Grassland Science, National Agriculture and, Food Research Organization (NARO), Tsukuba, Ibaraki 305-0901, Japan, Tel: (+81)-29-838-8614; Fax: (+81)-29-838-8623; E-mail: mkomatsu@affrc.go.jp

Received date: 20 March 2014, Accepted date: 12 June 2014, Published date: 20 June 2014

Copyright: @ 2014 Komatsu M, et al. This is an open-access article distributed under the terms of the Creative Commons Attribution License, which permits unrestricted use, distribution, and reproduction in any medium, provided the original author(s) and source are credited.

\begin{abstract}
The growth hormone secretagogue receptor 1a (GHSR1a) is involved in many important functions including growth hormone $(\mathrm{GH})$ secretion and appetite regulation and other important functions. We reveal herein, the unravelling of bovine-specific 5'untranslated region (5'UTR) microsatellite polymorphisms, a 3bp-indel in exon 1 (DeIR242) and two different kinds of transcripts of the GHSR1a gene (spliced, without a microsatellite with in the 5'UTR (GHSR1a); and non-spliced, with the microsatellite (GHSR1b)). A number of 17 alleles $((T G) 10 \sim 33)$ in the 5'UTR microsatellite was found in 11 cattle breeds. Furthermore, we found the DeIR242 (3R) allele, a truncated 3arginine residue (3R) (major type: 4 arginine residues (4R)) within the intracellular loop 3 of GHSR1a protein in Japanese Shorthorn with a high frequency of 0.43 compared to the low frequency of $0.00 \sim 0.09$ in other cattle breeds. We carried out a genetic association study between the 5'UTR microsatellite and growth and carcass traits in 1,285 steers. Statistical analysis revealed that the 5'UTR microsatellite locus had a significant additive effect on carcass weight (CW) and average daily gain (ADG). The 19-TG allele had a significantly desirable effect on these traits. We proposed a translational hypothesis that the association is due to differences in the secondary structure of GHSR $1 b$ mRNA among the GHSR1a gene haplotypes. We also examined age-related changes in the expressions of GHSR1a and GHSR1b in many cattle tissues. The GHSR1a mRNA expression in the arcuate nucleus of postweaning calves was more than 10-fold higher than those of pre-weaning calves and cows. In peripheral tissues, there were 3 marked differences in mRNA expression between cattle, humans and mice, as follows: (1) the GHSR1a mRNA expression in the liver is high in cattle and very low in humans and mice; (2) the GHSR1b mRNA expression in the liver is low in cattle and high in humans; (3) the GHSR1b mRNA expression in the pancreas is very high in cattle.
\end{abstract}

Keywords: Ghrelin Receptor (GHSR); Microsatellite; DelR242; mRNA expression; mRNA secondary structure; Growth and carcass traits; Cattle

\section{Bovine-Specific Nucleotide Polymorphisms of the GHSR 1a Gene and Its Genetic Association with Growth and Carcass Traits}

The growth hormone secretagogue receptor 1a (GHSR1a), also known as ghrelin receptor, is involved in many important functions including growth hormone $(\mathrm{GH})$ secretion, appetite regulation, energy balance and other important functions [1,2]. In cattle, the GHSR1a gene was reported as a potential candidate gene when we detected growth trait QTLs in Japanese Black cattle using microsatellite DNA markers and half-sib regression analysis [3]. With respect to the bovine GHSRla gene, it is of great interest that a polymorphic microsatellite $\left((T G)_{n}\right)$ is located within the 5 - flanking region of this locus [4], because no microsatellite had ever been found within the GHSR1a locus in either humans [5], mice [6] or rats [7]. However, there was no published report on nucleotide polymorphisms from the 5'-flanking region to the 3'-UTR nor on the transcriptional analysis of the 5'-UTR of the GHSRla gene in cattle. Therefore, we revealed for the first time, novel nucleotide polymorphisms from the 5'-flanking region to the 3'UTR $(\sim 6 \mathrm{~kb})$ and two different kinds of transcripts (spliced, without a microsatellite within 5'UTR (GHSR1a); and nonspliced, with the microsatellite (GHSR1b)) of the bovine GHSR1a gene (Figure 1) [8]. The nucleotide sequencing of this gene $(\sim 6 \mathrm{~kb})$ revealed 47 single nucleotide polymorphisms (SNPs), 4 indels and the two microsatellites $\left((T G)_{n}\right)$ in 5'UTR and $(G T T T)_{n}$ in Intron 1). A number of 17 alleles (10-TG to 33-TG) was found in the 5'UTR microsatellite locus in 11 cattle breeds. There were breed differences in allele frequencies and major alleles. Specifically, in Japanese Black cattle, the major alleles were 19-TG, 23-TG and 24-TG; alleles 19-TG, 21-TG, 22-TG, 23-TG and 24-TG in European cattle breeds, and alleles 10-TG and 22-TG in Philippine native cattle breeds (a mixture of Bos indicus and Bos taurus types). Short repeat number alleles 10$T G, 15-T G, 16-T G$ and $18-T G$ were found in the Philippine native cattle. The microsatellite TG-repeat sequences included one 
Citation: Komatsu M, Sato Y, Fujimori Y, Itoh T, Satoh M, et al. (2014) Bovine-Specific Nucleotide Polymorphisms and mRNA Expression of the Growth Hormone Secretagogue Receptor 1a (GHSR1a) Gene and its Genetic Association with Growth and Carcass Traits. J Mol Genet Med 8: 110. doi:10.4172/1747-0862.1000110

Page 2 of 5

cytosine $(\mathrm{C})$ instead of guanine $(\mathrm{G})$ at the 9 th repeat position from the $3^{\prime}$-end of this locus of 7 alleles $\left((T G)_{10 \sim 24} T(C)(T G)_{8}\right)$. This position was constant and independent of the TG-repeat number. These results suggest that the TG-repeat number of microsatellites increased with evolution from the 3 '-end to the 5 '-end direction of this sequence (Figure 1).

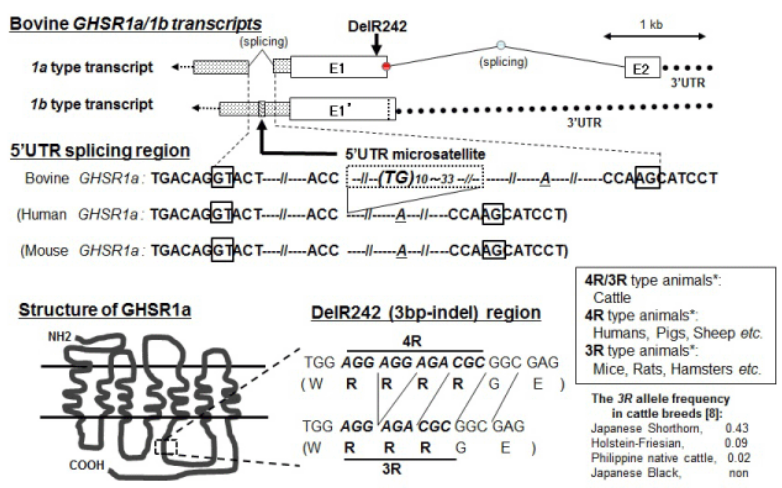

Figure 1: Bovine GHSR1a/1b transcripts, 5'UTR splicing region, structure of the GHSR1a and DelR242 region. Square boxes indicate 5' splice site (GT) and 3' splice site (AG). The underlined $A$ is the branch point. Dashed box is the 5'UTR microsatellite region. ${ }^{*}$ Several nucleotide differences in the DelR242 region are observable between animals.

We investigated the genetic association between the 5'UTR microsatellite $\left((T G)_{n}\right)$ of the GHSR1a gene and growth and carcass traits in Japanese Black cattle [9]. We used a population of 1,285 Japanese Black steers in a progeny-testing program of the Livestock Improvement Association of Japan (LIAJ). Genetic association analysis between DNA markers, growth and carcass traits was carried out using a univariate model within the framework of a derivative-free restricted maximum likelihood algorithm as applied in the MTDFREML [10]. MTDFREML statistical analysis clearly revealed that the 19-TG allele, one of the four major microsatellite alleles, had a very significant additive substitution effect on carcass weight $(\mathrm{CW})$ $(\mathrm{P}<0.0007)$, and average daily gain $(\mathrm{ADG})(\mathrm{P}<0.0002)$. Besides, the $A$ allele of the $n t-7(C>A)$ locus also had a significant effect on these traits $(\mathrm{CW}: \mathrm{P}<0.002)$; ADG: $\mathrm{P}<0.05)$. To further investigate the combined effect of both the 5'UTR microsatellite $\left((T G)_{n}\right)$ and $n t-\lambda(C>A)$ on these traits, haplotypes of the 5'UTR microsatellite $\left((T G)_{n}\right)$ and the $n t-\lambda(C>A)$ were constructed and statistically analyzed. The results demonstrated that the $[19-T G]-[A]$ haplotype had the most significant additive effect on these growth and carcass traits.

It has been reported that GT repeat polymorphisms in Tilapia prolactin 1 ( prl 1) 5'UTR promoter are associated with differences in prl 1 gene expression and the growth response of salt-challenged fishes [11]. The length of the TG-repeat in the P1 promoter region of the growth hormone receptor $(G H R)$ gene was significantly related to growth and carcass traits in beef cattle $[12,13]$. Stepwise increase in repeat numbers from 0 to 21 for a CA-microsatellite located in the promoter of the human matrix metalloproteinase- 9 gene has been reported to produce incremental surges in transcription rates [14]. Furthermore, a review of the simple sequence repeats (SSRs) in the 5'UTR by Li et al. [15] revealed that the regulation of gene expression is affected by both transcription and translation. Therefore, a logical explanation for the association between 5'UTR microsatellite $\left((T G)_{n}\right)$ polymorphism and growth traits is through differences in transcriptional or splicing or translational levels of the GHSR1a gene. The first, a "transcriptional hypothesis" is that the differences in DNA structure around the 5'UTR microsatellite region between [19-TG] and [non-19-TG] simultaneously affect transcriptional levels of both the $1 a$ and $1 b$ mRNAs from the $1 a$ gene. However, this hypothesis is hard to explain using the GHSR1b function because it has been reported that GHSRIb (the truncated receptor polypeptide) acts as a dominant-negative mutant of the GHSR1a (functional Ghrelin receptor) due to the formation of GHSR1a/GHSR1b heterodimer [16]. The second, a "splicing hypothesis" is that 5'UTR microsatellite $\left((T G)_{n}\right)$ in the intron affects the efficiency of alternative splicing of an adjacent exon in pre-mRNA (e.g. Cystic fibrosis $[17,18]$ for review]). However, this hypothesis seems to have low potential because the GHSR1a mRNA is the only spliced mRNA as there are no other alternative splicing variants. Moreover, the position of 5'UTR microsatellite is neither adjacent to 5' splice site (GT) nor 3' splice site (AG) [(GT)-//-(111 bases)-//-(5'UTR microsatellite)-//-(95bases)-//(AG)]. The third, a "translational hypothesis", is more intriguing and interesting as it relates to the differences in RNA secondary structure around the 5'UTR region of the $1 b$ mRNAs between the [19-TG] and [non-19-TG], thus affecting translational levels of $1 b$ mRNAs but not la mRNAs. McClelland et al. [19] reported that translational efficiency is inversely correlated with the stability of the mRNA secondary structure, the presence of base-pairing in the consensus Kozak sequence, the number of start codons in the 5'UTR and the length of the 5'UTR. In order to test this "translational hypothesis", we predicted the optimal RNA secondary structure of the GHSR1a and GHSR $1 b$ mRNAs using the Vienna RNA secondary structure server (http://rna.tbi.univie.ac.at/cgi-bin/RNAfold.cgi; RNA fold web server) [20]. The mRNA sequences of 6 haplotypes (haplotypes frequency: > 0.04 ) were analyzed. The results showed that the secondary structure around the 5'UTR microsatellite region of the [19-TG]-1b mRNAs had a unique structure that was different from those of [non-19-TG], thus $[19-T G]$ seemed to have a small dominant negative effect on the translation efficiency of GHSRIb mRNA due to its unique structure. Therefore, the GHSRIb mRNA translation efficiency based on the secondary structure of the 5'UTR microsatellite regions seems to be in the following order: $[$ non-19-TG] $>$ [19-TG]. On the other hand, the optimal RNA secondary structures of the la mRNAs appeared to be almost the same among haplotypes and there seemed to be no differences in GHSR1a mRNA translation efficiency and GHSR1a protein level among these haplotypes. On the basis of these results, we proposed a translational hypothesis that differences in the RNA secondary structure of GHSR1b mRNAs among the 5'UTR microsatellite affect the functional level of the Ghrelin receptor (GHSR1a). The function of GHSR1b has been suggested to regulate GHSR1a expression in the form of GHSR1a/GHSR1b heterodimer [16]. Furthermore, the GHSR1b attenuates the constitutive activation of phosphatidylinositol-specific phospholipase $\mathrm{C}$ by ghrelin receptors but has no effect on ghrelin-stimulated extracellular signal [21]. The estimated functional Ghrelin receptor levels of each homozygote are [the GHSRIa protein level] minus [GHSRIb protein level] and in the following order: [19-TG] $>$ [non-19-TG]. The differences in RNA secondary structure around the 5'UTR region of $1 b$ mRNAs between [19-TG] and [non-19-TG] affect translational levels of $1 b$ mRNAs and the functional Ghrelin receptor level during growth, GH release from the pituitary gland, plasma GH concentration, appetite, glyconeogenesis and finally, growth traits in cattle [9]. This hypothesis should be validated by a molecular biological study in the future. 
Citation: Komatsu M, Sato Y, Fujimori Y, Itoh T, Satoh M, et al. (2014) Bovine-Specific Nucleotide Polymorphisms and mRNA Expression of the Growth Hormone Secretagogue Receptor 1a (GHSR1a) Gene and its Genetic Association with Growth and Carcass Traits. J Mol Genet Med 8: 110. doi:10.4172/1747-0862.1000110

Page 3 of 5

The DelR242 in Exon 1 is a 3 -bp (AGG) indel (Figure 1). This mutation causes a truncated 3-arginine residue $(3 R)$ (normal type: 4 arginine residues $(4 R)$ ) of the third loop of the intercellular loop (ICL) domain of the GHSR1a protein. The $3 R$ is a fundamental allele of the GHSRla gene in mice, rats and Chinese hamsters. The $4 R$ is a fundamental allele in humans, pigs and sheep. Furthermore, in humans, two missense mutations (p.R237W and p.D246A) adjacent to the 4R region of ICL3 of the GHSR1a protein have been reported in short-stature families [22,23]. These GHSR1a gene mutations displayed a partial loss of constitutive activity in the GHSR1a receptor. We found an interesting breed difference in the $3 R$ allele frequency which was high (0.43) in Japanese Shorthorn and low (0.09) in Holstein-Friesian cattle. This allele was never found in Japanese Black cattle (Figure 1 ). The $3 R$ allele is widely distributed in many cattle breeds and may be an older allele than the $4 R$ allele [8]. The DelR242 locus and/or the $3 R$ allele may have some significant effects on growth and feeding behavior in Japanese Shorthorn cattle. To further investigate the reason for a higher frequency of the $3 R$ allele of the GHSRla gene in Japanese Shorthorn cattle than other cattle breeds, a research project is in progress (manuscript in preparation).

To find a species specific motif within the promoter region of the GHSR1a gene in cattle, we compared potential transcriptional regulatory sequences in approximately $2.6 \mathrm{~kb}$ of the 5 -flanking region the GHSRla gene among cattle, humans and mice [8]. Six bovine specific motifs were identified as follows: (1) Apolipoprotein E_B1, (2) A-activator binding site (AABS), (3) S1 nuclease-hypersensitive site, (4) Nuclear protein factors and erythroid specific 1_CS1, (5) Nuclear protein factors I, and (6) Nuclear factor_E1. Apolipoprotein E (apoE) is a major constituent of very low density lipoprotein and can be found associated with all of the major classes of lipoprotein particles [24]. Furthermore, AABS motif is a binding site for C/EBP beta (CCAAT/ enhancer-binding protein beta) [25]. C/EBP beta is a transcriptional regulator of the UCP1 (uncoupling protein-1) gene, the specific marker gene of brown adipocytes responsible for thermo genic capacity [26]. mRNA expression of the GHSR1a gene in cattle may be more coordinated with lipoprotein metabolism than those of humans and mice.

\section{Bovine-specific mRNA expression of the GHSRla gene}

Age-related changes in the GHSR1a mRNA expression have been reported in rats [27] and in mice [28]. Furthermore, comprehensive tissue distributions of the GHSR1a and/or GHSR1b mRNA expressions have been reported in humans [29] and in mice [28] However, in cattle, no comprehensive tissue distributions of the GHSR1a and/or GHSR1b mRNA expressions in the arcuate nucleus, pituitary gland and other bovine tissues had been reported in cattle. Therefore, in order to develop a better understanding of the agerelated functions of GHSR1a and GHSR1b in the hypothalamus/ pituitary-mediated regulation of GH secretion and feeding/growth in cattle, we examined the age-related changes in the GHSR1a and GHSR1b mRNA expressions in several tissues including the arcuate nucleus and pituitary gland by real-time PCR [30]

Age-related changes in relative expression levels of the GHSR1a and GHSR $1 b$ mRNAs in five tissues including the arcuate nucleus are shown in Table 1. The expression level of GHSR1a mRNA in the arcuate nucleus during the post-weaning age was more than 10 -fold higher than in pre-weaning calves and the mature cow. The expression level of GHSR1b mRNA did not change significantly among age groups. In the pituitary gland, the expression level of GHSR1a and GHSR $1 b$ mRNAs declined with age.

\begin{tabular}{|c|c|c|c|c|c|c|}
\hline \multirow{3}{*}{$\begin{array}{l}\text { Age } \\
\text { Tissues }\end{array}$} & \multicolumn{3}{|c|}{ GHSR1a mRNA } & \multicolumn{3}{|c|}{ GHSR $1 b$ mRNA } \\
\hline & $\begin{array}{l}\text { Pre- } \\
\text { weaning }\end{array}$ & $\begin{array}{l}\text { Post- } \\
\text { weaning }\end{array}$ & Cow & $\begin{array}{l}\text { Pre- } \\
\text { weaning }\end{array}$ & $\begin{array}{l}\text { Post- } \\
\text { weaning }\end{array}$ & Cow \\
\hline & \multicolumn{2}{|c|}{ Mean $\left(\log _{10}\right)^{*}$} & \multicolumn{3}{|c|}{ Mean $\left(\log _{10}\right)^{*}$} & \\
\hline $\begin{array}{l}\text { Arcuate } \\
\text { nucleus }\end{array}$ & 0.85 & 2.14 & 0.96 & 0.64 & 0.31 & 0.86 \\
\hline Pituitary & 1.97 & 1.01 & 1.31 & 1.81 & 0.73 & 1.31 \\
\hline Liver & 1.11 & 1.13 & 0.76 & 0.05 & 0.21 & 0.04 \\
\hline Spleen & 0.02 & 0.09 & 0.35 & 0.88 & 1.85 & 1.68 \\
\hline $\begin{array}{l}\text { Pancrea } \\
\mathrm{s}\end{array}$ & - & -0.40 & 0.29 & - & 1.72 & 2.32 \\
\hline
\end{tabular}

Table 1: Age-related changes in relative expression levels of GHSR1a and GHSR1b mRNAs in several tissues in cattle [30]. ${ }^{*}$ Data are expressed relative to $G A P D H$ mRNA $\left\{\log _{10}\right.$ ([copy number of GHSR1a mRNA or GHSR1b mRNA in $1 \mu \mathrm{g}$ total RNA / copy number of GAPDH mRNA in $1 \mu \mathrm{g}$ total RNA] 1,000)\}. Pre-weaning: 19- to 26day-old male calves; Post-weaning: 2- to 6.5-month-old steer; Cow: 3.2- to 8.1- year-old cow.

Ghrelin / GHSR stimulate appetite in the arcuate nucleus [1,31]. In the arcuate nucleus, the ghrelin-containing neurons send efferent fibers onto neuropeptide Y (NPY)- and agouti-related protein (AgRP)expressing neurons to stimulate the release of these orexigenic peptides and onto proopiomelanocortin (POMC) to suppress the release of anorexigenic peptide in rodents [32]. In sheep, offering feed ad libitum (resulting in greater ME intake), decreased hypothalamic mRNA expression of NPY and AgRP and tended to increase that of POMC compared with feed-restricted wethers [33]. The GHSR1a mRNA detected in NPY and GHRH neurons in the arcuate nucleus and GHSR1a are involved in the up-regulation of NPY and GHRH expression in the arcuate nucleus [34]. In cattle, absolute body weight gain $(\mathrm{kg})$ per month is larger in the post-weaning period than during the pre-weaning phase and adulthood [35]. Voluntary feed intake increases significantly with age and reaches or exceeds 'adult' levels within 6 weeks after weaning [36]. Furthermore, voluntary feed intake per unit of metabolic weight (dry matter (g) / live weight (kg)/ day) from weaning to sexual maturity shows a steady decline with increasing weight [37]. Itoh et al. [38] and ThidarMyint et al. [39] observed that GH response to ghrelin and growth-hormone-releasing hormone $(\mathrm{GHRH})$ stimulation in post-weaning calves is greater than in pre-weaning calves and cows, but no synergistic effects of ghrelin indicates that in the post-weaning period, the very high expression of GHSRIa mRNA and relatively lower expression of GHSR1b mRNA in the arcuate nucleus, dramatically amplify ghrelin signaling that stimulates the release of orexigenic peptides (eg, NPY, AgRP, GHRH). These conditions also suppress the release of anorexigenic peptides (eg, -melanocyte stimulating hormone) as well as the secretion of GH in cattle. Therefore, post-weaning calves exhibit a very high voluntary feed intake.

In peripheral tissues, there were 3 marked differences in mRNA expression between cattle (ruminants), humans and mice (monogastric animals), as follows: (1) GHSR1a mRNA expression in the liver is high in cattle and very low in humans and mice; (2) 
Citation: Komatsu M, Sato Y, Fujimori Y, Itoh T, Satoh M, et al. (2014) Bovine-Specific Nucleotide Polymorphisms and mRNA Expression of the Growth Hormone Secretagogue Receptor 1a (GHSR1a) Gene and its Genetic Association with Growth and Carcass Traits. J Mol Genet Med 8: 110. doi:10.4172/1747-0862.1000110

Page 4 of 5

GHSR1b mRNA expression in the liver is low in cattle and high in humans; (3) GHSR1b mRNA expression in the pancreas is very high in cattle (Table 2).

\begin{tabular}{|c|c|c|c|c|c|}
\hline \multirow{2}{*}{$\begin{array}{l}\text { Expressi } \\
\text { on level }\end{array}$} & \multicolumn{3}{|l|}{ GHSR1a } & \multicolumn{2}{|l|}{ GHSR1b } \\
\hline & Cow & Human & Mouse & Cow & Human \\
\hline \multirow[t]{5}{*}{ High } & Pituitary & Pituitary & Pituitary & Pancreas & Myocardium \\
\hline & $\begin{array}{l}\text { Arcuate } \\
\text { nucleus }\end{array}$ & Thyroid & Brain & Spleen & Pituitary \\
\hline & Liver & $\begin{array}{l}\text { Pancre } \\
\text { as }\end{array}$ & Heart & Pituitary & Thyroid \\
\hline & Spleen & Spleen & Thymus & $\begin{array}{l}\text { Arcuate } \\
\text { nucleus }\end{array}$ & Pancreas \\
\hline & Pancreas & Adrenal & testes & $\begin{array}{l}\text { Adipose } \\
\text { tissue }\end{array}$ & Ileum/Colon \\
\hline \multirow{5}{*}{ Low } & $\begin{array}{l}\text { Mammary } \\
\text { gland }\end{array}$ & & Lung & Kidney & Liver \\
\hline & Adipose tissue & & Adrenal & $\begin{array}{l}\text { Mammary } \\
\text { gland }\end{array}$ & Breast \\
\hline & Kidney & & $\begin{array}{l}\text { small } \\
\text { intestine }\end{array}$ & Liver & Spleen \\
\hline & Heart & & spleen & $\begin{array}{l}\text { Skeletal } \\
\text { muscle }\end{array}$ & Duodenum \\
\hline & $\begin{array}{l}\text { Skeletal } \\
\text { muscle }\end{array}$ & & Pancreas & Heart & Placenta \\
\hline
\end{tabular}

Table 2: Tissue expression levels of GHSR1a and GHSR1b mRNAs in cow [30], human [29] and mouse [28]. Age: cow, 3.2- to 8.1-year old cow; human, unknown; mouse, 6-wk-old male.

Murata et al. [40] reported that GHSR1a mRNA is expressed in hepatoma cells and that ghrelin up-regulates the mRNA level of phosphoenolpyruvate carboxykinase (PEPCK), which is the ratelimiting enzyme of glyconeogenesis and modulates downstream molecules involved in insulin-signaling in humans. Furthermore, GHSRla and ghrelin mRNAs are expressed in human T lymphocytes and monocytes, where ghrelin acts via GHSR1a to especially inhibit the expression of pro-inflammatory anorectic cytokines such as IL-6, IL- $1 \beta$ and TNF- $\alpha$ [41]. IL-6 is well-known to inhibit the expression of the glyconeogenic genes (phosphoenolpyruvate carboxylase-1(PCK-1) and glucose 6-phosphatase (G6PC)) in the liver via the signal transducer and activator of the transcription-3 (STAT-3) signal cascade [42]. Since hepatic and renal gluconeogenesis is crucially important in glucose metabolism in ruminants [43], the high expression of GHSR1a mRNA and the low expression of GHSR1b mRNA in the liver seem to be important for gluconeogenesis and represent the bovine-specific expression pattern for maintaining glucose homeostasis in cattle. The very high expression of splenic GHSR1b mRNA described may attenuate the inhibition of proinflammatory anorectic cytokines and leptin-induced anorectic cytokine expression in monocytes and $\mathrm{T}$ cells by the action of ghrelin via GHSR1a for maintaining the immune system and appetite control. Ghrelin is expressed in pancreatic islets and there appears to be a negative association between ghrelin and insulin secretion from the pancreas in vivo [44]. Ghrelin has been known to function as a potent inhibitor of pancreatic cholecystokinin (CCK)-induced exocrine secretion in rats [44], and the $\mathrm{CCK}_{\mathrm{A}}$ and $\mathrm{CCK}_{\mathrm{B}}$ /gastrin receptors, which are $\mathrm{G}$ protein-coupled receptors (GPCRs), are expressed in the pancreas in cattle [45]. Moreover, pancreatic polypeptide (PP) is expressed by PP cells in the endocrine pancreas and is released in response to meals as an anorexigenic peptide. A receptor with a high affinity for PP, the Y4 receptor, which is also a GPCR, is expressed in the human pancreas [46]. In addition, the GHSR1b and neurotensin receptor 1 (NTSR1) have been shown to be overexpressed in human non-small cell lung cancers (NSCLC), and that a heterodimer complex of these receptors (GHSR1b/NTSR1) functioned as a neuromedin $\mathrm{U}$ (NMU) receptor. A very high expression of GHSR1b mRNA in the pancreas may support the hypothesis that the GHSRIb alters the basal expression of GHSR1a by the GHSR1a - GHSR1b heterodimer formation [16]. Furthermore, other GPCRs expressed in the pancreas, such as the $\mathrm{CCK}_{\mathrm{A}}$ and $\mathrm{CCK}_{\mathrm{B}}$ /gastrin receptors and $\mathrm{Y} 4$ receptor, may interact with $G H S R 1 b$ to alter basal expression of these receptors and to ensure a ready response to changes in nutritional / physiological body conditions. Further investigation on the relationship among these receptors is needed.

Bovine-specific nucleotide polymorphisms and mRNA expression of the GHSRla gene described in this mini review will contribute to a better understanding of functions of the GHSRIa and GHSR1b.

\section{References}

1. Cruz CR, Smith RG (2008) The growth hormone secretagogue receptor. Vitam Horm 77: 47-88.

2. Muccioli G, Baragli A, Granata R, Papotti M, Ghigo E (2007) Heterogeneity of ghrelin/growth hormone secretagogue receptors. Toward the understanding of the molecular identity of novel ghrelin/GHS receptors. Neuroendocrinology 86: 147-164.

3. Malau-Aduli AEO, Niibayashi T, Kojima T, Oshima K, Mizoguchi Y, et al. (2005) Mapping the quantitative trait loci (QTL) for body shape and conformation measurements on BTA1 in Japanese Black cattle. Anim Sci J 76: 19-27.

4. Ma RZ, Russ I, Park C, Heyen DW, Beever JE, et al. (1996) Isolation and characterization of 45 polymorphic microsatellites from the bovine genome. Anim Genet 27: 43-47.

5. Kaji H, Tai S, Okimura Y, Iguchi G, Takahashi Y, et al. (1998) Cloning and characterization of the 5 -flanking region of the human growth hormone secretagogue receptor gene. J Biol Chem 273: 33885-33888.

6. Okazaki Y, Furuno M, Kasukawa T, Adachi J, Bono H, et al. (2002) Analysis of the mouse transcriptome based on functional annotation of 60,770 full-length cDNAs. Nature 420: 563-573.

7. McKee KK, Palyha OC, Feighner SD, Hreniuk DL, Tan CP, et al. (1997) Molecular analysis of rat pituitary and hypothalamic growth hormone secretagogue receptors. Mol Endocrinol 11: 415-423.

8. Komatsu M, Fujimori Y, Sato Y, Okamura H, Sasaki S, et al. (2010) Nucleotide polymorphisms and the 5'-UTR transcriptional analysis of the bovine growth hormone secretagogue receptor 1a (GHSR1a) gene. Anim Sci J 81: 530-550.

9. Komatsu M, Itoh T, Fujimori Y, Satoh M, Miyazaki Y, et al. (2011) Genetic association between GHSR1a 5'UTR-microsatellite and $n t-7(C>A)$ loci and growth and carcass traits in Japanese Black cattle. Anim Sci J 82: 396-405.

10. Boldman K, Kriese LA, Van Vleck LD, Kachmen SD (1993) A manual for use of MTDFREML, 1-115. USDA. Washington DC.

11. Streelman JT, Kocher TD (2002) Microsatellite variation associated with prolactin expression and growth of salt-challenged tilapia. Physiol Genomics 9: 1-4.

12. Hale CS, Herring WO, Shibuya H, Lucy MC, Lubahn DB, et al. (2000) Decreased growth in angus steers with a short TG-microsatellite allele in 
Citation: Komatsu M, Sato Y, Fujimori Y, Itoh T, Satoh M, et al. (2014) Bovine-Specific Nucleotide Polymorphisms and mRNA Expression of the Growth Hormone Secretagogue Receptor 1a (GHSR1a) Gene and its Genetic Association with Growth and Carcass Traits. J Mol Genet Med 8: 110. doi:10.4172/1747-0862.1000110

Page 5 of 5

the P1 promoter of the growth hormone receptor gene. J Anim Sci 78: 2099-2104.

13. Curi RA, Oliveira HN, Silveira AC, Lopes CR (2005) Effects of polymorphic microsatellites in the regulatory region of IGF1 and GHR on growth and carcass traits in beef cattle. Anim Genet 36: 58-62.

14. Shimajiri S, Arima N, Tanimoto A, Murata Y, Hamada T, et al. (1999) Shortened microsatellite $d(C A) 21$ sequence down-regulates promoter activity of matrix metalloproteinase 9 gene. FEBS Lett 455: 70-74.

15. Li YC, Korol AB, Fahima T, Nevo E (2004) Microsatellites within genes: structure, function, and evolution. Mol Biol Evol 21: 991-1007.

16. Leung PK, Chow KB, Lau PN, Chu KM, Chan CB, et al. (2007) The truncated ghrelin receptor polypeptide (GHS-R1b) acts as a dominantnegative mutant of the ghrelin receptor. Cell Signal 19: 1011-1022.

17. Cuppens H, Lin W, Jaspers M, Costes B, Teng H, et al. (1998) Polyvariant mutant cystic fibrosis transmembrane conductance regulator genes: the polymorphic (TG)n locus explains the partial penetrance of the T5 polymorphism as a disease mutation. J Clin Invest 101: 487-496.

18. Faustino NA, Cooper TA (2003) Pre-mRNA splicing and human disease. Genes Dev 17: 419-437.

19. McClelland S, Shrivastava R, Medh JD (2009) Regulation of Translational Efficiency by Disparate 5' UTRs of PPARgamma Splice Variants. PPAR Res 2009: 193413.

20. Hofacker IL (2003) Vienna RNA secondary structure server. Nucleic Acids Res 31: 3429-3431.

21. Ghu KM, Chow KBS, Leung PK, Lau PN, Chan CB, et al. (2007) Overexpression of the truncated ghrelin receptor polypeptide attenuates the constitutive activation of phosphatidylinositol-specific phospholipase C by ghrelin receptors but has no effect on ghrelin-stimulated extracellular signal-regulated kinase 1/2 activity. Int J Biochem Cell Biol 39:752-764.

22. Pantel J, Legendre M, Nivot S, Morisset S, Vie-Luton MP, et al. (2009) Recessive isolated growth hormone deficiency and mutations in the ghrelin receptor. J Clin Endocrinol Metab 94: 4334-4341.

23. Inoue H, Kangawa N, Kinouchi A, Sakamoto Y, Kimura C, et al. (2011) Identification and functional analysis of novel human growth hormone secretagogue receptor (GHSR) gene mutations in Japanese subjects with short stature. J Clin Endocrinol Metab 96: E373-378.

24. Smith JD, Melián A, Leff T, Breslow JL (1988) Expression of the human apolipoprotein $\mathrm{E}$ gene is regulated by multiple positive and negative elements. J Biol Chem 263: 8300-8308.

25. Guo Z, Shao L, Feng X, Reid K, Marderstein E, et al. (2003) A critical role for $\mathrm{C} / \mathrm{EBPb}$ ta binding to the AABS promoter response element in the human iNOS gene. FASEB J 17: 1718-1720.

26. Carmona MC, Hondares E, Rodríguez de la Concepción ML, RodríguezSureda V, et al. (2005) Defective thermoregulation, impaired lipid metabolism, but preserved adrenergic induction of gene expression in brown fat of mice lacking C/EBPß. Biochem J 389:47-56.

27. Kamegai J, Wakabayashi I, Kineman RD, Frohman LA (1999) Growth hormone-releasing hormone receptor (GHRH-R) and growth hormone secretagogue receptor (GHS-R) mRNA levels during postnatal development in male and female rats. J Neuroendocrinol 11: 299-306.

28. Sun Y, Garcia JM, Smith RG (2007) Ghrelin and growth hormone secretagogue receptor expression in mice during aging. Endocrinology 148: 1323-1329.

29. Gnanapavan S, Kola B, Bustin SA, Morris DG, McGee P, et al. (2002) The tissue distribution of the mRNA of ghrelin and subtypes of its receptor, GHS-R, in humans. J Clin Endocrinol Metab 87: 2988.

30. Komatsu M, Kojima M, Okamura H, Nishio M, Kaneda M, et al. (2011) Gene expression of the growth hormone secretagogue and growthhormone-releasing hormone receptors in Holstein-Friesian cattle: Agerelated changes in the arcuate nucleus, pituitary gland and other tissues. Domest Anim Endocrinol 42:83-83
31. Kojima M, Kangawa K (2005) Ghrelin: structure and function. Physiol Rev 85: 495-522.

32. Anderson LL, Jeftinija S, Scanes CG, Stromer MH, Lee JS, et al. (2005) Physiology of ghrelin and related peptides. Domest Anim Endocrinol 29: 111-144.

33. Relling AE, Pate JL, Reynolds CK, Loerch SC (2010) Effect of feed restriction and supplemental dietary fat on gut peptide and hypothalamic neuropeptide messenger ribonucleic acid concentrations in growing wethers. J Anim Sci 88: 737-748.

34. Mano-Otagiri A, Nemoto T, Sekino A, Yamauchi N, Shuto Y, et al. (2006) Growth hormone-releasing hormone (GHRH) neurons in the arcuate nucleus (Arc) of the hypothalamus are decreased in transgenic rats whose expression of ghrelin receptor is attenuated: Evidence that ghrelin receptor is involved in the up-regulation of GHRH expression in the arc. Endocrinology 147: 4093-4103.

35. Morrison FB (1959) Feeds and feeding. (22nd eds), Morrison Publishing Company, Clinton, Iowa.

36. Hodgeson J (1971) The development of food intake in calves. 4. The effect of the addition of material to the rumen, or its removal from the rumen, on voluntary food intake. Anim Prod 13:581-592.

37. Forbes JM (1986) Effects of physiological state and animal productivity: The voluntary food intake of farm animals. (Forbes JM, ed), Butterworth \& Co. London

38. Itoh F, Komatsu T, Yonai M, Sugino T, Kojima M, et al. (2005) GH secretory responses to ghrelin and GHRH in growing and lactating dairy cattle. Domest Anim Endocrinol 28: 34-45.

39. ThidarMyint $\mathrm{H}$, Yoshida $\mathrm{H}$, Ito $\mathrm{T}$, He $\mathrm{M}$, Inoue $\mathrm{H}$, et al. (2008) Combined administration of ghrelin and GHRH synergistically stimulates GH release in Holstein preweaning calves. Domest Anim Endocrinol 34: 118-123.

40. Murata M, Okimura Y, Iida K, Matsumoto M, Sowa H, et al. (2002) Ghrelin modulates the downstream molecules of insulin signaling in hepatoma cells. J Biol Chem 277: 5667-5674.

41. Dixit VD, Schaffer EM, Pyle RS, Collins GD, Sakthivel SK, et al. (2004) Ghrelin inhibits leptin- and activation-induced proinflammatory cytokine expression by human monocytes and T cells. J Clin Invest 114: 57-66.

42. Inoue H, Ogawa W, Ozaki M, Haga S, Matsumoto M, et al. (2004) Role of STAT-3 in regulation of hepatic gluconeogenic genes and carbohydrate metabolism in vivo. Nat Med 10: 168-174.

43. Leat WMF (1970) Carbohydrate and lipid metabolism in the ruminant during post-natal development: Digestive physiology and metabolism in the ruminants. (Phillipson AT, ed), Oriel Press Ltd, Newcastle Upon Tyne, England.

44. Date Y, Nakazato M, Kangawa K, Matsuo H (2004) Gastro-enteropancreatic actions of ghrelin: Ghrelin. (Ghigo E, ed), Kluwer Academic Publishers, Norwell, MA.

45. Desbois C, Clerc P, Le Huërou-Luron I, Le Dréan G, Gestin M, et al. (1998) Differential tissular expression of the CCK(A) and CCK(B) gastrin receptor genes during postnatal development in the calf. Life Sci 63: 2059-2070.

46. Lundell I, Blomqvist AG, Berglund MM, Schober DA, Johnson D, et al. (1995) Cloning of a human receptor of the NPY receptor family with high affinity for pancreatic polypeptide and peptide YY. J Biol Chem 270: 29123-29128.

47. Takahashi K, Furukawa C, Takano A, Ishikawa N, Kato T, et al. (2006) The neuromedin U-growth hormone secretagogue receptor $1 \mathrm{~b} /$ neurotensin receptor 1 oncogenic signaling pathway as a therapeutic target for lung cancer. Cancer Res 66: 9408-9419. 